IZA DP No. 7494

Exporting and Labor Demand:

Micro-Level Evidence from Germany

Andreas Lichter

Andreas Peichl

Sebastian Siegloch

July 2013 


\title{
Exporting and Labor Demand: Micro-Level Evidence from Germany
}

\author{
Andreas Lichter \\ IZA and University of Cologne \\ Andreas Peichl \\ IZA, University of Cologne, ISER and CESifo \\ Sebastian Siegloch \\ IZA and University of Cologne
}

Discussion Paper No. 7494

July 2013

IZA
P.O. Box 7240
53072 Bonn
Germany

Phone: $+49-228-3894-0$

Fax: +49-228-3894-180

E-mail: iza@iza.org

Any opinions expressed here are those of the author(s) and not those of IZA. Research published in this series may include views on policy, but the institute itself takes no institutional policy positions. The IZA research network is committed to the IZA Guiding Principles of Research Integrity.

The Institute for the Study of Labor (IZA) in Bonn is a local and virtual international research center and a place of communication between science, politics and business. IZA is an independent nonprofit organization supported by Deutsche Post Foundation. The center is associated with the University of Bonn and offers a stimulating research environment through its international network, workshops and conferences, data service, project support, research visits and doctoral program. IZA engages in (i) original and internationally competitive research in all fields of labor economics, (ii) development of policy concepts, and (iii) dissemination of research results and concepts to the interested public.

IZA Discussion Papers often represent preliminary work and are circulated to encourage discussion. Citation of such a paper should account for its provisional character. A revised version may be available directly from the author. 


\section{ABSTRACT \\ Exporting and Labor Demand: Micro-Level Evidence from Germany*}

It is widely believed that globalization increases the volatility of employment and decreases the bargaining power of workers. One mechanism explaining this relationship is given by the long-standing Hicks-Marshall laws of derived demand: with international trade increasing competition and therefore the price elasticity of product demand, exporters are predicted to have higher labor demand elasticities. Our paper is the first to test this relationship empirically by analyzing the effects of exporting on firms' labor demand. Using rich, administrative linked employer-employee panel data from Germany, we explicitly control for issues of self-selection and endogeneity in the firms' decisions to export by providing fixed effects and instrumental variable estimates. Our results show that exporting indeed has a positive and significant effect on the own-wage elasticity of unconditional labor demand, due to higher price elasticities of product demand.

JEL Classification: F16, F66, J23

Keywords: trade, export, labor demand, wage elasticity, microdata, Germany

Corresponding author:

Andreas Lichter

IZA

P.O. Box 7240

53072 Bonn

Germany

E-mail: lichter@iza.org

\footnotetext{
* The authors thank David Autor, Sarra Ben Yahmed, Philipp Dörrenberg, Daniel S. Hamermesh, Alexander Hijzen, Gerard A. Pfann as well as participants at the IAB Establishment Panel Survey Conference, the 6th RGS Doctoral Conference, the CESifo-Delphi Conference on "The Economics of Firm Exporting" and the LEED workshop in Lisbon for helpful comments and suggestions.
} 


\section{Introduction}

It is widely believed that globalization increases the volatility of employment and decreases the bargaining power of workers (Rodrik, 1997). While (accelerating) international trade is rather a modern phenomenon, the theoretical mechanism explaining higher worker vulnerability is well established: one of the Hicks-Marshall laws of derived demand states that the higher the own-wage elasticity of labor demand, ceteris paribus, the higher the price elasticity of product demand Hamermesh, 1993). Given that recent empirical evidence suggests that firms' international engagement increases the price elasticity of product demand and the sales volatility (Vannoorenberghe, 2012; Nguyen and Schaur, 2012), it follows that exporting firms should have a more elastic demand for labor. In this paper, we use German administrative linked employer-employee data from 1996 to 2008 to provide a first empirical test of this long-standing law $\mathrm{L}^{1}$

We add to the existing literature in four ways. First, by analyzing whether unconditional own-wage labor demand elasticities differ with the exporting status and intensity of firms, we explicitly investigate the theoretical implication of larger scale effects for exporting firms due to fierce competition or lower market power. Second, we add to the growing literature on the characteristics of exporting firms. In general, exporters are larger both in terms of output and employment, more productive and pay higher wages than those firms merely serving their domestic markets (see, Bernard et al., 2007 for an overview). However, it has been shown that most differences are not caused by the sheer act of exporting itself, but rather by the self-selection of particularly productive firms into exporting (Bernard and Jensen, 1995; Clerides et al., 1998). Thus, we thirdly address endogeneity and selection issues by applying a firm fixed effects, instrumental variables estimator in the spirit of Autor et al. (2013) using exports to China as an instrument. Finally, from a data point of view, studies analyzing the impact of globalization on labor demand have moved from using country-level to industry- and firm-level data. By using administrative linked employer-employee micro-level panel data, we are able

\footnotetext{
${ }^{1}$ Focusing on Germany is particularly interesting in this context, since the German economy is heavily reliant on exports, with the share of exports on national GDP amounting to around $50 \%$ and with around a quarter of all jobs depending on exporting (Yalcin and Zacher, 2011).
} 
to base our estimations on a rich set of establishments and their employees.

Our empirical results provide evidence for the Hicks-Marshall law of derived demand as both the exporting status and intensity increases overall unconditional own-wage labor demand elasticities. ${ }^{2}$ In absolute terms, the unconditional ownwage elasticity of labor demand tends to be around 10-15\% higher for an average exporting establishment compared to a similar non-exporting establishment. We find the same pattern when estimating labor demand elasticities separately for different skill groups: while own-wage elasticities are generally higher for blue-collar than for white-collar workers, exporting both at the extensive and intensive margin increases elasticities for all skill and collar groups. Our estimates hence suggest that wage premiums for workers employed in exporting firms come at the cost of higher employment volatility and might serve as a compensation for higher job insecurity.

While our finding of higher unconditional labor demand elasticities for exporting firms might be explained by the Hicks-Marshall law of derived demand and hence a larger scale effect for exporting firms, it might also be caused by higher labor demand elasticities conditional on output. Matsuyama (2007)'s theoretical model shows that exporting and non-exporting firms might also exhibit differences in conditional labor demand for heterogeneous worker groups, and we investigate this potential channel by analyzing whether conditional own-wage elasticities differ for exporting and non-exporting firms. However, as our results show that overall conditional elasticities are similar for exporting and non-exporting firms, we are able to rule out this channel. In a last step, we use our estimates of conditional and unconditional labor demand to derive price elasticities of product demand for exporting and non-exporting establishments following Hijzen and Swaim $(2010)$. We find the mean price elasticity of product demand to be considerably higher for exporting than for non-exporting establishments, which validates the Hicks-Marshall law of derived demand.

The remainder of this paper is structured as follows. Section 2 provides a discussion of the related literature, focusing on the effects of globalization on the

\footnotetext{
${ }^{2}$ When speaking of higher/larger or lower/smaller own-wage elasticities, we refer to absolute values throughout the whole paper. Hence, a higher wage elasticity means 'more negative' and thus de facto a wage elasticity with a lower value.
} 
elasticity of labor demand as well as on differences between exporting and nonexporting firms. We subsequently present our empirical model in Section 3. Section 4 describes the dataset used in our analysis and presents some basic descriptive statistics on the differences between exporting and non-exporting establishments. We present and discuss our empirical results in Section 5, placing special emphasis on the issue of endogeneity. Section 6 concludes.

\section{Related Literature}

There are two broad strands of related literature that we combine in our paper: studies analyzing (i) the effects of globalization on the elasticity of labor demand; and (ii) the differences between exporting and non-exporting firms, as well as the causal effect of exporting on firm behavior.

In terms of the first strand, the analysis of different features of globalization and their corresponding effects on labor demand has attracted much attention in the literature. Slaughter (2001) provides first empirical evidence on the effects of international trade on the own-wage elasticity of labor demand. While his findings suggest that (non-production) production labor has (not) become more elastic in manufacturing industries over time in the US, he finds only weak evidence for a direct effect of trade. Exploiting exogenous variation caused by trade liberalization reforms in low- and middle-income countries, several studies analyze the causal effect of trade liberalization on the elasticity of labor demand. Krishna et al. (2001) for Turkey as well as Fajnzylber and Maloney (2005) for Chile, Columbia and Mexico find no significant empirical link between trade liberalization and the absolute value of own-wage elasticities. In contrast, Hasan et al. (2007) provide evidence that trade reforms in India raise the own-wage elasticity of labor demand in absolute terms, a finding that Mitra and Shin (2012) confirm by analyzing the interaction effects of trade liberalization reforms, importing and exporting behavior in South Korea 3

\footnotetext{
${ }^{3}$ Clearly, these studies are related to our work as trade liberalization increases firms' opportunities to sell their goods abroad, given that it increases competition through imports. However, the respective studies do not explicitly derive the effect of exporting on the elasticity of labor demand but rather the overall effect of trade openness.
} 
Focussing on one key aspect of globalization, several studies analyze labor demand effects of firms' decision to outsource production processes, with the results suggesting that labor demand elasticities for (un-)skilled workers increase (decrease) (Hijzen et al., 2005; Senses, 2010; Hijzen and Swaim, 2010), but not in every country (Fajnzylber and Fernandez, 2009). Other studies investigate whether labor demand elasticities differ between multinational and domestic firms. Evidence on this topic is mixed, ranging from findings on higher absolute own-wage labor demand elasticities for multinational compared to domestic firms (Fabbri et al., 2003; Görg et al., 2009, Hakkala et al., 2010), no significant differences (Buch and Lipponer, 2010) to less elastic demand for labor by multinationals (Navaretti et al., 2003).

In respect of the second strand of the literature, a variety of stylized facts on the differences between exporting and non-exporting firms has been established. Among others, exporting firms are larger both in terms of output and employment, more productive and pay higher wages than comparable non-exporting firms (see, for example, Bernard and Jensen, 1995; Bernard et al., 2007). Evidence for Germany is provided by Schank et al. (2007) who - controlling for observable and unobservable employee- and firm-characteristics - report wage premia for workers employed in exporting firms, as well as by Wagner (2007), who finds exporting firms to be more productive than non-exporting firms. Most differences, however, do not stem from the mere act of exporting goods to foreign markets. Clerides et al. (1998) and Bernard and Jensen (1999), for example, show that only the most productive firms select into exporting whereas no significant productivity gains occur after entering the export market. ${ }^{4}$ Bustos (2011) shows that firms raise additional revenues by participating in international trade and use these to adopt better technologies. In addition, Matsuyama (2007) theoretically argues that the act of exporting is afflicted with specific skill-intensive tasks - a theoretical prediction that Brambilla et al. (2012) do not confirm empirically using Argentine firm-level data. Their estimates rather show that export destinations matter, with only those firms demanding a higher than average share of skilled labor that sell their products to high-income

\footnotetext{
4 Aw et al. (2000) and Delgado et al. (2002) find similar evidence; however, Van Biesebroeck (2005) and De Loecker (2007) report productivity gains from exporting for Sub-Saharan African manufacturing firms and Slovenian firms during the transition from a plan to market economy, respectively.
} 
countries. Finally, recent empirical evidence shows that exporting firms face higher overall sales volatility. Using panel data on French manufacturing firms, Vannoorenberghe (2012) shows that the firms' export share in total sales has a statistically and economically significant positive effect on their overall sales volatility. Nguyen and Schaur (2012) find similar results for Danish manufacturing firms.

\section{Empirical Specification}

We follow standard practice as proposed in Hamermesh (1993) and derive unconditional labor demand by assuming establishments to maximize their current profits. In line with Hijzen and Swaim (2010), the empirical specification used to estimate unconditional demand for overall employment is given by the following equation:

$$
\ln l_{i t}=\alpha \ln w_{i t}+\delta \ln w_{i t} e_{i t}+\gamma e_{i t}+\boldsymbol{\beta} \mathbf{X}_{i t}^{\prime}+\eta_{i}+\boldsymbol{\varphi}_{i t}+\epsilon_{i t}
$$

The term $\ln l_{i t}$ denotes the logarithm of establishment's overall employment, $\ln w_{i t}$ the $\log$ mean wage rate and $e_{i t}$ the respective export status, defined by either a dummy variable or the actual export share in total sales. $\mathbf{X}_{\mathbf{i t}}$ is a row vector of additional covariates, including log investments of the previous year, the share of intermediate inputs and a dummy variable indicating whether wages are set under some form of collective bargaining agreement. We also include establishment fixed effects $\left(\eta_{i}\right)$ as well as industry-year fixed effects, which are summarized by row vector $\boldsymbol{\varphi}_{i t} ; \varepsilon_{i t}$ is the error term.

When estimating unconditional demand for $J$ heterogeneous types of labor we slightly adjust equation (1):

$$
\ln l_{i t}^{j}=\sum_{j=1}^{J} \alpha_{j} \ln w_{i t}^{j}+\delta \ln w_{i t}^{j} e_{i t}+\gamma e_{i t}+\boldsymbol{\beta} \mathbf{X}_{i t}^{\prime}+\eta_{i}+\boldsymbol{\varphi}_{i t}+\epsilon_{i t} .
$$

The dependent variable becomes log employees of labor type $j$, thus we replace $\ln l_{i t}$ with $\ln l_{i t}^{j}$. Furthermore, we replace $\alpha \ln w_{i t}$ with $\sum_{j=1}^{J} \alpha_{j} \ln w_{i t}^{j}$ and $\delta \ln w_{i t} e_{i t}$ with $\delta \ln w_{i t}^{j} e_{i t}$. As the model is estimated in logarithms, the unconditional own-wage elasticities for heterogeneous worker groups are given by: 


$$
\left.\frac{\partial \ln l_{i t}^{j}}{\partial \ln w_{i t}^{j}}\right|_{e=0}=\alpha_{j} \quad \text { and }\left.\quad \frac{\partial \ln l_{i t}^{j}}{\partial \ln w_{i t}^{j}}\right|_{e>0}=\alpha_{j}+\delta e_{i t} \cdot 5
$$

The term $\delta e_{i t}$ on the right-hand side of equation (3) explicitly represents the effect of exporting on the elasticity of labor demand. As the error terms of the unconditional demand equations for different types of labor are likely to be correlated within establishment, we estimate the set of equations jointly using Zellner (1962)'s seemingly unrelated regression (SUR) estimation procedure, while accounting for firm fixed effects $\eta_{i}$ by demeaning the data. When not differentiating between different labor types (i.e. estimating equation (1)), we use a simple fixed effects estimator, clustering standard errors at the establishment level.

By using the within establishment variation to identify the effect of exporting on labor demand, we explicitly account for self-selection into exporting. Establishment fixed effects additionally control for unobserved time-invariant confounders, such as plant location, which might affect both left and right-hand side variables. In addition, we control for industry-year fixed effects, which capture any industryspecific shocks.6 ${ }^{6}$ However, the establishment's export behavior and labor demand may still depend on unobserved time-varying firm-level factors, notably productivity gains. Hence, the establishment's export share in total sales $\left(e_{i t}\right)$ as well as the corresponding interaction term with the wage rate $\left(w_{i t} e_{i t}\right)$ may be endogenous, which could bias our estimates 7

We explicitly account for the issue of endogeneity by applying an instrumental variables (IV) strategy. Conceptually, we follow Autor et al. (2013), who instrument U.S. imports of Chinese goods by changes in other high-income countries' imports stemming from China. We adjust their approach by instrumenting the individual establishment's export share in total sales with the corresponding industry's log value of exports destined for China. The instrument is derived at the two-digit

${ }^{5}$ The unconditional own-wage elasticities for overall employment are obtained accordingly.

${ }^{6}$ We differentiate between five broad industries within the manufacturing sector: cars, steel, durables, food and non-durables.

${ }^{7}$ Imagine unobserved gains in productivity causing a higher export share and higher level of employment. For a given wage rate, this would induce an upward bias of the interaction term between wages and the export share. Therefore, accounting for this sort of endogeneity should lead to more negative estimates of the interaction term. Consequently, our fixed effects estimates might serve as a lower bound. 
industry level (23 industries within manufacturing) using yearly foreign trade data provided by the Federal Statistical Office. Technically, we follow the procedure suggested by Wooldridge (2010) and run a first-stage regression of the export share on the instrument. In the second stage, we use the predicted export share and corresponding wage interaction as instruments in equation 1.

\section{Data and Descriptive Statistics}

Our study is based on administrative linked employer-employee data from Germany. In the present context, using German data is of particular interest as its economy heavily depends on the export of its goods and services. Germany's export share of GDP (approximately 50\%) is considerably higher compared to most other developed countries 8 , with around two-thirds of all German exports stemming from the manufacturing sector (Mayer and Ottaviano, 2008). Moreover, Germany's strong reliance on exporting is reflected by the fact that around one quarter of all jobs depend either directly or indirectly on exports (Yalcin and Zacher, 2011).

\subsection{Data}

We base our analysis on the $L I A B$ dataset provided by the Institute of Employment Research (IAB).$^{9}$ Utilization of linked employer-employee data is crucial for our study, as we need to observe both individual-specific variables such as employees' occupations, qualifications and wages, as well as establishment information on output or export intensity in order to analyze the effects of exporting on the elasticities of labor demand for heterogeneous worker groups.

The employee data is a two percent random sample of the administrative employment statistics of the German Federal Employment Agency, which covers all employees paying social security contributions (payroll taxes) or receiving unemployment benefits. Thus, the dataset does not cover self-employed or civil servants as they are not subject to social security contributions. Among others, the dataset

\footnotetext{
8 See World Trade Organization $(2012)$ for the 2011 statistics and Figure A.1 in the Appendix.

9 See Alda et al. (2005) for detailed information on this dataset.
} 
comprises detailed information on the individuals' qualification and occupation, their employment type (full-time, part-time or irregular employment) as well as their daily wage, right-censored at the upper earnings threshold of social security contributions. In turn, the $I A B$ establishment panel is a representative, stratified, random sample of German establishments with at least one employee liable to social security. As indicated by the name, the dataset focuses on the establishment rather than on the aggregate, namely the firm. It has covered West and East German establishments since 1996 and contains various information on the establishments' business and employment structure, such as data on investments, turnover, staff and the export share in total sales.

Following common practice, we restrict our analysis to the manufacturing sector as it accounts for the lion's share of Germany's total exports and displays substantial heterogeneity in terms of employment, export intensity and output ${ }^{10}$ Moreover, we focus on full-time employees (the vast majority in manufacturing) and restrict our analysis to establishments with at least five employees. Following Fajnzylber and Maloney (2005), we account for heterogeneous effects of trade for different groups of workers by distinguishing between blue- and white-collar labor. Relying on worker-specific occupational information, we assign each employee to one of the two occupational categories. Given that there is substantial heterogeneity among blue-collar workers, we further split this group by educational achievement. We classify employees to be high-skilled blue-collar workers in the case that they either hold a tertiary college degree, received the highest German high-school diploma (Abitur) or completed vocational training. All other blue-collar workers are considered to be low-skilled. We adjust all monetary variables for inflation, notably wages and output, relying on the German consumer price index obtained from the German Federal Statistical Office. Our sample spans the period of 1996 to 2008 and ultimately comprises 5,939 establishments, which are, on average, observed 4.76 times during this period. This amounts to 28,285 establishment-year and around 7 million worker-year observations.

\footnotetext{
10 Helpman et al. (2012) reason for substantial heterogeneity in Brazilian manufacturing firms and we also find this heterogeneity for the German case.
} 


\subsection{Descriptive Statistics}

According to our data, an establishment's decision to engage in exporting tends to be a long-term choice. We find that $92 \%$ of all manufacturing establishments that have exported some share of their output in one year did so in each year of our sample. Similarly, $88 \%$ of those establishments that only served the domestic market in one year remained non-exporters during the whole sample period. In line with previous research, simple descriptive analysis further shows considerable differences between exporting and non-exporting establishments (Table 1). On average, exporting establishments are considerably larger in terms of both output and employment, more capital-intensive and more productive than non-exporting establishments ${ }^{11}$ In addition, exporting establishments pay higher wages and employ a slightly higher share of white-collar workers. Interestingly, the share of low-skilled blue-collar workers is also higher for exporting than for non-exporting establishments (18 vs. 11\%). To

Table 1: Characteristics of non-exporting and exporting establishments

\begin{tabular}{|c|c|c|c|}
\hline $\begin{array}{l}\text { Mean values of } \\
\text { establishment characteristics }\end{array}$ & $\begin{array}{l}\text { Non-Exporting } \\
\text { establishments }\end{array}$ & $\begin{array}{l}\text { Exporting } \\
\text { establishments }\end{array}$ & $\begin{array}{l}\text { Whole } \\
\text { sample }\end{array}$ \\
\hline Export share (in \%) & - & 33.05 & 18.47 \\
\hline No. of workers & 66.18 & 389.92 & 247.15 \\
\hline \multicolumn{4}{|l|}{ Workforce share } \\
\hline of high-skilled blue-collar workers (in \%) & 64.01 & 56.03 & 59.55 \\
\hline of white-collar workers (in \%) & 24.60 & 26.16 & 25.47 \\
\hline of low-skilled blue-collar workers (in \%) & 11.39 & 17.81 & 14.98 \\
\hline \multicolumn{4}{|l|}{ Monthly wage } \\
\hline overall & $2,240.98$ & $2,912.57$ & $2,616.39$ \\
\hline for high-skilled blue-collar workers & $2,200.36$ & $2,779.42$ & $2,525.75$ \\
\hline for white-collar workers & $2,433.95$ & $3,368.77$ & $2,977.43$ \\
\hline for low-skilled blue-collar workers & $2,012.86$ & $2,435.76$ & $2,293.23$ \\
\hline Value-added per worker & $68,355.90$ & $98,603.23$ & $85,263.82$ \\
\hline Log output & 14.78 & 16.90 & 15.96 \\
\hline Investments per worker & $7,849.28$ & $9,785.15$ & $8,999.48$ \\
\hline Share of intermediate inputs (in \%) & 44.98 & 48.36 & 46.87 \\
\hline
\end{tabular}

Source: Own computations based on LIAB data. Note: Mean values of different establishments characteristics. All monetary values are given in Euros, the shares in percentage points.

further investigate these differences, we follow Bernard et al. (2007) and estimate simple bivariate OLS equations, regressing an export dummy variable on various firm characteristics. We note that our data features many stylized facts on the differences between exporting and non-exporting firms reported in the literature

11 We proxy productivity by the logarithm of establishments' value-added per worker and acknowledge that this single-factor proxy might not capture their overall productivity. See Syverson (2011) for a discussion of productivity measures. 
(cf. Section 2). However, the effects of exporting on different firm characteristics become smaller when including additional covariates into these regressions. Detailed results are provided in Table A.1 in the Appendix.

\section{Empirical Results}

The aim of this paper is to test whether the Hicks-Marshall law holds true empirically. Intuitively, we expect exacerbated competition on foreign markets to render exporting establishments' labor demand more elastic than the demand for labor of non-exporting establishments. We start our analysis by investigating the effect of exporting on the elasticity of unconditional labor demand, both at the extensive and intensive margin (5.1). In the second part of this section (5.2), we abstract from scale effects by extending our analysis to conditional labor demand in order to back out the price elasticity of product demand.

\subsection{The Elasticity of Unconditional Demand}

We start by presenting our results obtained from fixed effects estimations at both the extensive (via a dummy variable) and intensive margin (by means of the establishment's export share in total sales). Recall that each specification contains industry-year fixed effects, capturing aggregate and industry-specific shocks over time, as well as establishment fixed effects. Table 2 reports the baseline results. The overall unconditional wage elasticity is -0.66 in specification (1) and thus of reasonable magnitude for a static long-run elasticity (Hamermesh, 1993). More interestingly, we find that exporting has the expected effect on the own-wage elasticity of unconditional labor demand as indicated by the negative and significant interaction term of the log wage and export dummy: exporting increases the absolute value of the own-wage elasticity of labor demand by around 10 percent. We next turn to the intensive margin, substituting the export dummy variable with the establishment's export share in total sales. The results provided in column (2) of Table 2 mirror those presented in column (1), as we find that the establishment's export share has a positive and significant effect on the (absolute value of the) overall own- 
wage elasticity of labor demand. We are able to infer that the own-wage elasticity of labor demand for the average exporting establishment is 0.099 points (around 15\%) higher than for a comparable non-exporting establishment 12 Hence, the magnitude of the effect is also similar to that presented in column (1).

Table 2: Labor demand and exporting: baseline results (fixed effects)

\begin{tabular}{|c|c|c|c|c|}
\hline Dep. var.: log overall number of workers & \multicolumn{2}{|c|}{ Whole sample } & \multirow{2}{*}{$\begin{array}{c}\begin{array}{c}\text { Exporting } \\
\text { plants only }\end{array} \\
\begin{array}{c}0.797^{* * *} \\
(0.153)\end{array}\end{array}$} & \multirow{2}{*}{$\begin{array}{c}\text { No change } \\
\text { in export status } \\
-0.630^{* * *} \\
(0.104)\end{array}$} \\
\hline Log wage & $\begin{array}{c}-0.662^{* * *} \\
(0.087)\end{array}$ & $\begin{array}{c}-0.643^{* * *} \\
(0.086)\end{array}$ & & \\
\hline Log wage*export dummy & $\begin{array}{c}-0.067^{* *} \\
(0.031)\end{array}$ & & & \\
\hline Log wage*export share & & $\begin{array}{c}-0.003^{* * *} \\
(0.001)\end{array}$ & $\begin{array}{c}-0.003^{*} \\
(0.001)\end{array}$ & $\begin{array}{c}-0.004^{* *} \\
(0.002)\end{array}$ \\
\hline Export dummy & $\begin{array}{c}0.564^{* *} \\
(0.242)\end{array}$ & & & \\
\hline Export share & & $\begin{array}{c}0.027^{* * *} \\
(0.008)\end{array}$ & $\begin{array}{c}0.021^{* *} \\
(0.010)\end{array}$ & $\begin{array}{c}0.030^{* *} \\
(0.013)\end{array}$ \\
\hline Collective bargaining agreement & $\begin{array}{c}0.001 \\
(0.010)\end{array}$ & $\begin{array}{c}0.001 \\
(0.010)\end{array}$ & $\begin{array}{c}0.006 \\
(0.015)\end{array}$ & $\begin{array}{c}0.007 \\
(0.013)\end{array}$ \\
\hline Log investments & $\begin{array}{c}0.030^{* * *} \\
(0.002)\end{array}$ & $\begin{array}{c}0.030^{* * *} \\
(0.002)\end{array}$ & $\begin{array}{c}0.031^{* * *} \\
(0.003)\end{array}$ & $\begin{array}{c}0.029^{* * *} \\
(0.003)\end{array}$ \\
\hline (Share of intermediate inputs/100) & $\begin{array}{c}-0.016^{*} \\
(0.010)\end{array}$ & $\begin{array}{l}-0.016 \\
(0.010)\end{array}$ & $\begin{array}{c}-0.029^{* *} \\
(0.013)\end{array}$ & $\begin{array}{l}-0.017 \\
(0.011)\end{array}$ \\
\hline Number of observations & 22,953 & 22,953 & 13,947 & 16,971 \\
\hline Number of groups & 5,612 & 5,612 & 3,621 & 4,374 \\
\hline Overall R-Squared & 0.110 & 0.109 & 0.103 & 0.123 \\
\hline
\end{tabular}

Source: Own computations based on LIAB data. Note: All specifications include establishment and industry-year fixed effects. The constant is omitted for the ease of presentation. Standard errors (in parentheses) are clustered at the establishment level. Significance levels are $0.1\left(^{*}\right), 0.05(* *)$, and $0.01\left(^{* * *}\right)$.

Selection into exporting. In the next two specifications, we check the robustness of the baseline results with respect to firms' selection into exporting. In column (3), we restrict the sample to exporting firms only, thus focusing on the potentially selected group of exporting establishments. We find that the wage elasticity increases slightly compared to model (2), although we cannot reject that the two coefficients are identical. Moreover, the interaction term remains statistically significant, which indicates that labor demand elasticities increase with the exporting intensity - even within the group of exporters. This finding suggests that our effects are not driven by selection into exporting. Our model in column (4), where we restrict the sample to establishments that do no change their export status over the observation pe-

\footnotetext{
${ }^{12}$ Recall that the average export share of exporting establishments is $33 \%$.
} 
riod, corroborates this conjecture. Again, we find very similar estimates to those of specification (2).

Instrumental variables. As discussed in Section 3, our estimates would be biased if establishments' employment decision and export behavior were both affected by unobserved time-varying factors. In Table 3 we thus present our estimates obtained from an IV approach, where we follow Autor et al. (2013) and instrument the establishment's export share and the corresponding wage interaction term with the respective industry's log value of exports destined for China. As discussed in Section

Table 3: Labor demand and exporting: IV estimates

\begin{tabular}{|c|c|c|c|}
\hline \multirow[b]{2}{*}{ Dep. var.: log overall number of workers } & \multirow{2}{*}{$\begin{array}{c}\text { Fixed effects } \\
\text { IV sample } \\
(2000-2008)\end{array}$} & \multicolumn{2}{|c|}{ Instrumental variables } \\
\hline & & $\begin{array}{l}\text { IV sample } \\
(2000-2008)\end{array}$ & $\begin{array}{c}\text { No change } \\
\text { in export status }\end{array}$ \\
\hline Log wage & $\begin{array}{c}-0.597^{* * *} \\
(0.089)\end{array}$ & $\begin{array}{c}-0.534^{* * *} \\
(0.105)\end{array}$ & $\begin{array}{c}-0.532^{* * *} \\
(0.135)\end{array}$ \\
\hline Log wage*export share & $\begin{array}{c}-0.003^{* *} \\
(0.001)\end{array}$ & $\begin{array}{l}-0.008^{*} \\
(0.005)\end{array}$ & $\begin{array}{l}-0.008 \\
(0.006)\end{array}$ \\
\hline Export share & $\begin{array}{c}0.021^{* *} \\
(0.008)\end{array}$ & $\begin{array}{l}0.067^{*} \\
(0.037)\end{array}$ & $\begin{array}{c}0.069 \\
(0.048)\end{array}$ \\
\hline Collective bargaining agreement & $\begin{array}{c}0.014 \\
(0.009)\end{array}$ & $\begin{array}{l}0.010 \\
(0.09)\end{array}$ & $\begin{array}{c}0.019 \\
(0.012)\end{array}$ \\
\hline Log investments & $\begin{array}{c}0.027^{* * *} \\
(0.002)\end{array}$ & $\begin{array}{c}0.028^{* * *} \\
(0.002)\end{array}$ & $\begin{array}{c}0.025^{* * *} \\
(0.003)\end{array}$ \\
\hline (Share of intermediate inputs/100) & $\begin{array}{l}-0.015 \\
(0.011)\end{array}$ & $\begin{array}{l}-0.014 \\
(0.013)\end{array}$ & $\begin{array}{l}-0.015 \\
(0.014)\end{array}$ \\
\hline Number of observations & 18,012 & 14,629 & 10,607 \\
\hline Number of groups & 4,937 & 3,613 & 2,717 \\
\hline Underidentification test (Kleibergen-Paap statistic) & & 67.67 & 53.78 \\
\hline Weak identification test (Kleibergen-Paap statistic) & & 49.36 & 32.605 \\
\hline Endogeneity test (p-value) & & 0.321 & 0.421 \\
\hline
\end{tabular}

Source: Own computations based on LIAB data. Note: All specifications include establishment and industry-year fixed effects. The constant is omitted for the ease of presentation. Standard errors (in parentheses) in column (1) are clustered at the establishment level. Standard errors in columns (2) and (3) are heteroscedasticity robust and clustered at the establishment level. Significance levels are $0.1\left(^{*}\right), 0.05(* *)$, and $0.01\left({ }^{* *}\right)$.

3. we use two-digit trade data to construct our estimates. However, such data is only available for the years 2000 to 2008. Therefore, we first present baseline fixed effects estimates on the restricted sample of 2000-2008 to enable the comparison of our estimates. In line with our previous results, the export share in total sales has a positive effect on the own-wage elasticity of unconditional labor demand. In column (2) we turn to our IV estimates. We first note that our model is well identified: allowing for heteroscedasticity in the errors, the Kleibergen-Paap test statistics 
suggest that the excluded instruments are relevant and not weak 13 Considering the regression estimates, we find that the point estimate of the interaction term of the establishment's export share and the wage rate becomes more negative when accounting for endogeneity, which suggests that endogeneity would bias our fixed effects estimates towards zero, as argued above. However, we cannot reject that the interaction terms in column (1) and (2) of Table 3 are identical, which indicates that endogeneity problems are negligible in our context. This finding is supported by the endogeneity test reported at the bottom of the table, where we fail to reject exogeneity of the potentially endogenous variables (export share and the corresponding wage interaction term) in the IV estimations. Consequently, our preferred specification is column (2) of Table 2, given that simple fixed effects estimation yields more efficient results (Wooldridge, 2010). In the last column of Table (3), we again test the robustness of our results by restricting the sample to continuous exporters and non-exporters only. We note that our results remain robust to the restrictions imposed, albeit with the interaction term turning insignificant.

The demand for heterogeneous labor. Given that, in Western countries, lowskilled workers are most likely to be negatively affected by globalization and increased international competition, we next analyze whether exporting has differential effects on establishments' unconditional demand for heterogeneous types of labor, distinguishing between low-skilled blue-collar, high-skilled blue-collar and white-collar workers. In line with the IV results, we treat the export dummy (export share) and corresponding interaction terms as exogenous and only report fixed effects estimates. Moreover, we estimate model equation (2) using SUR to account for the fact that the error terms of the unconditional demand equations for different types of labor are likely to be correlated within the establishment ${ }^{14}$

Table 4 shows that all estimates of own-wage labor demand elasticities are negative and statistically different from zero. Moreover, own-wage demand elasticities for white-collar labor are lower than for blue-collar labor. Among the blue-collar

\footnotetext{
13 The corresponding first-stage regressions are given in Table B.2 in the Appendix, where we also report the corresponding First-Stage F-test statistics, which are well above 10.

${ }^{14}$ We report the corresponding estimates obtained by simple fixed effects in Table C.3 in the Appendix of this paper.
} 
workers, we further report higher unconditional own-wage elasticities for high-skilled than for low-skilled labor 15

Table 4: Labor demand \& exporting: heterogeneous labor

\begin{tabular}{|c|c|c|c|c|c|c|}
\hline \multirow[b]{2}{*}{ Dep. var.: log number of skilled workers } & \multicolumn{3}{|c|}{ Extensive margin } & \multicolumn{3}{|c|}{ Intensive margin } \\
\hline & high/blue & white & low/blue & high/blue & white & low/blue \\
\hline Log high-skilled blue-collar wage & $\begin{array}{c}-1.019^{* * *} \\
(0.037)\end{array}$ & $\begin{array}{c}-0.060^{*} \\
(0.036)\end{array}$ & $\begin{array}{c}-0.259^{* * *} \\
(0.052)\end{array}$ & $\begin{array}{c}-1.015^{* * *} \\
(0.037)\end{array}$ & $\begin{array}{l}-0.052 \\
(0.036)\end{array}$ & $\begin{array}{c}-0.247^{* * *} \\
(0.052)\end{array}$ \\
\hline Log white-collar wage & $\begin{array}{c}0.062^{* * *} \\
(0.023)\end{array}$ & $\begin{array}{c}-0.267^{* * *} \\
(0.026)\end{array}$ & $\begin{array}{c}-0.140^{* * *} \\
(0.034)\end{array}$ & $\begin{array}{c}0.064^{* * *} \\
(0.023)\end{array}$ & $\begin{array}{c}-0.260^{* * *} \\
(0.025)\end{array}$ & $\begin{array}{c}-0.136^{* * *} \\
(0.034)\end{array}$ \\
\hline Log low-skilled blue-collar wage & $\begin{array}{c}0.184^{* * *} \\
(0.021)\end{array}$ & $\begin{array}{c}0.059^{* * *} \\
(0.021)\end{array}$ & $\begin{array}{c}-0.663^{* * *} \\
(0.034)\end{array}$ & $\begin{array}{c}0.184^{* * *} \\
(0.021)\end{array}$ & $\begin{array}{c}-0.058^{* * *} \\
(0.021)\end{array}$ & $\begin{array}{c}-0.655^{* * *} \\
(0.032)\end{array}$ \\
\hline Log high-skilled blue-collar wage*export & $\begin{array}{c}-0.092^{* * *} \\
(0.022)\end{array}$ & & & & & \\
\hline Log white-collar wage*export & & $\begin{array}{c}-0.079^{* * *} \\
(0.020)\end{array}$ & & & & \\
\hline Log low-skilled blue-collar wage*export & & & $\begin{array}{c}-0.090^{* * *} \\
(0.029)\end{array}$ & & & \\
\hline Log high-skilled blue-collar wage*export share & & & & $\begin{array}{c}-0.003^{* * *} \\
(0.001)\end{array}$ & & \\
\hline Log white-collar wage*export share & & & & & $\begin{array}{c}-0.003^{* * *} \\
(0.001)\end{array}$ & \\
\hline Log low-skilled blue-collar wage*export share & & & & & & $\begin{array}{c}-0.003^{* * *} \\
(0.001)\end{array}$ \\
\hline Export dummy & $\begin{array}{c}0.759^{* * *} \\
(0.171)\end{array}$ & $\begin{array}{c}0.674^{* * *} \\
(0.160)\end{array}$ & $\begin{array}{c}0.718^{* * *} \\
(0.226)\end{array}$ & & & \\
\hline Export share & & & & $\begin{array}{c}0.023^{* * *} \\
(0.004)\end{array}$ & $\begin{array}{c}0.027^{* * *} \\
(0.004)\end{array}$ & $\begin{array}{c}0.026^{* * *} \\
(0.005)\end{array}$ \\
\hline Collective bargaining agreement & $\begin{array}{c}0.007 \\
(0.008)\end{array}$ & $\begin{array}{c}-0.024^{* * * *} \\
(0.008)\end{array}$ & $\begin{array}{c}0.005 \\
(0.011)\end{array}$ & $\begin{array}{c}0.008 \\
(0.008)\end{array}$ & $\begin{array}{c}-0.022^{* * *} \\
(0.008)\end{array}$ & $\begin{array}{c}0.005 \\
(0.011)\end{array}$ \\
\hline Log investments & $\begin{array}{c}0.029^{* * *} \\
(0.002)\end{array}$ & $\begin{array}{c}0.023^{* * *} \\
(0.002)\end{array}$ & $\begin{array}{c}0.038^{* * *} \\
(0.003)\end{array}$ & $\begin{array}{c}0.029^{* * *} \\
(0.002)\end{array}$ & $\begin{array}{c}0.023^{* * *} \\
(0.002)\end{array}$ & $\begin{array}{c}0.038^{* * *} \\
(0.003)\end{array}$ \\
\hline (Share of intermediate inputs/100) & $\begin{array}{c}-0.025^{* *} \\
(0.009)\end{array}$ & $\begin{array}{c}-0.038^{* * *} \\
(0.010)\end{array}$ & $\begin{array}{c}-0.051^{* * *} \\
(0.014)\end{array}$ & $\begin{array}{c}-0.025^{* *} \\
(0.009)\end{array}$ & $\begin{array}{c}-0.037^{* * * *} \\
(0.010)\end{array}$ & $\begin{array}{c}-0.050^{* * *} \\
(0.014)\end{array}$ \\
\hline No. of observations & 16,270 & 16,270 & 16,270 & 16,270 & 16,270 & 16,270 \\
\hline No. of groups & 4,100 & 4,100 & 4,100 & 4,100 & 4,100 & 4,100 \\
\hline R-Squared & 0.086 & 0.035 & 0.085 & 0.086 & 0.036 & 0.085 \\
\hline Breusch-Pagan test & 8394.2 & 8394.2 & 8394.2 & $8,395.7$ & $8,395.7$ & $8,395.7$ \\
\hline
\end{tabular}

Source: Own computations based on LIAB data. Note: Columns (1), (2) and (3) as well as (4), (5) and (6) are estimated jointly using fixed effects SUREG. All specifications include establishment and industry-year fixed effects. Standard errors (in parentheses). Significance levels are $0.1\left(^{*}\right), 0.05(* *)$, and $0.01(* * *)$. Note than "high blue", "white" and "low blue" denote the log number of high-skilled blue-collar, white-collar and low-skilled blue-collar workers, respectively. Note that the Breusch-Pagan statistics test for the independence (H0) of the residuals obtained from the three respective labor demand equations.

More interestingly, specifications (1) to (3) of Table 4 show that exporting in itself has both a statistically and economically significant effect on the unconditional own-wage demand elasticity for all types of labor, raising elasticities by around $8 \%$ to $22 \%$. Specifications (4) to (6) provide the corresponding results for the intensive

\footnotetext{
${ }^{15}$ However, given the share of high-skilled and low-skilled blue-collar labor in the total workforce, this result is not particularly surprising.
} 
margin. For each type of labor, we find the own-wage demand elasticities to significantly increase with the establishment's export share. Therefore, our results indicate that exporting at both the extensive and intensive margin renders the demand for each type of labor more elastic. Yet, we do not find that low-skilled workers are particularly negatively affected by increasing international activity of firms.

\subsection{Conditional Demand and Scale Effects}

So far, we have shown differences in unconditional labor demand elasticities for exporting and non-exporting firms. While this finding could be explained by the Hicks-Marshall law of derived demand and higher product demand elasticities of exporters, our results are not yet a proof of this law. Indeed, it might also be possible that exporting firms have different conditional labor demand elasticities. In fact, Matsuyama (2007) suggests that exporters face more skill-intensive tasks and thus have a higher demand for skilled labor, even when conditioning on output. To rule out that such differences drive our results, we additionally estimate conditional labor demand elasticities. In a second step, we can use conditional and unconditional labor demand elasticities to back out the price elasticity of product demand, i.e. the scale effect, by applying the fundamental law of demand (Hijzen and Swaim, 2010).

In terms of estimation, we follow standard practice to obtain conditional ownwage elasticities. We depart from a static, structural model of firm behavior where firms are assumed to minimize their costs given a constant level of output (for details, see Hamermesh, 1993). We specify costs via the flexible translog cost function (Diewert and Wales, 1987) and apply Shephard's lemma to derive the establishment's cost share equations. We estimate the cost share equations along with the cost function, allowing for non-constant returns to scale as well as imposing linear homogeneity in input prices $\sqrt{16}$ Conditional own-wage labor demand elasticities, $\bar{\mu}_{i i}$, are calculated as

$$
\bar{\mu}_{i i}=\frac{\alpha_{i i}-\widehat{S}_{i}+\widehat{S}_{i} \widehat{S}_{i}}{\widehat{S}_{i}} \quad \forall i=1, . ., I
$$

\footnotetext{
16 The system of equations is given in Appendix D.
} 
with $\widehat{S}_{i}$ being the predicted cost share of skill group $i$ and $\alpha_{i i}$ a coefficient from the regression model (see Appendix D).

As before, we distinguish between low-skilled blue-collar, high-skilled bluecollar and white-collar workers and estimate the model separately for exporting and non-exporting establishments, as well as for the whole sample. ${ }^{17}$ The set of equations is estimated by SUR, demeaning the data to account for establishment fixed effects. As the parameter estimates vary depending on the cost share discarded from the system of equations, we iterate our estimations until changes in the estimated parameters become arbitrarily small (Berndt and Wood, 1975) ${ }^{18}$

Figure 1 reports the mean values and confidence intervals of conditional ownwage labor demand elasticities for high-skilled blue-collar, white-collar, low-skilled blue-collar and overall labor. ${ }^{19}$ The left panel displays the overall conditional ownwage elasticities. We note that all elasticities are significantly different from zero and negative, as postulated by theory. Moreover, the estimated own-wage elasticities for high-skilled blue-collar and white-collar workers are of similar magnitudes, which is not surprising given that the majority of white-collar workers in manufacturing are high-skilled. In line with the empirical literature, the mean own-wage elasticity for low-skilled blue-collar labor is higher compared to the corresponding elasticities for high-skilled blue-collar and white-collar labor.

In the right panel of Figure 1, conditional own-wage labor demand elasticities are provided for exporting and non-exporting establishments separately. Again, all estimated own-wage elasticities are negative and statistically different from zero. When comparing the overall conditional elasticity, we find very similar values for exporting $(-0.41)$ and non-exporting establishments $(-0.45)$. The same picture

${ }^{17}$ Following Peichl and Siegloch $\sqrt{2012}$, we restrict the analysis of conditional labor demand to those establishments that employ at least three workers of each skill category to guarantee sufficient substitution possibilities.

${ }^{18}$ To ensure that our estimates are in line with the underlying theoretical assumptions, we follow Berndt (1991) and test whether the cost functions are monotonically increasing in input prices, the estimated cost shares are non-negative for each observation and whether the cost function is quasi-concave in input prices. Regression results and test statistics for the respective equations are provided in Tables D.5, D.6 and D.7 in the Appendix.

${ }^{19}$ Standard errors are obtained by bootstrapping the set of equations using 400 replications. All mean elasticities and the corresponding standard errors are provided in Table D.4 in the Appendix. The own-wage elasticities for overall employment are calculated as the establishment's average of the three estimated elasticities weighted by the respective cost share. 
Figure 1: Conditional own-wage elasticities for different types of labor

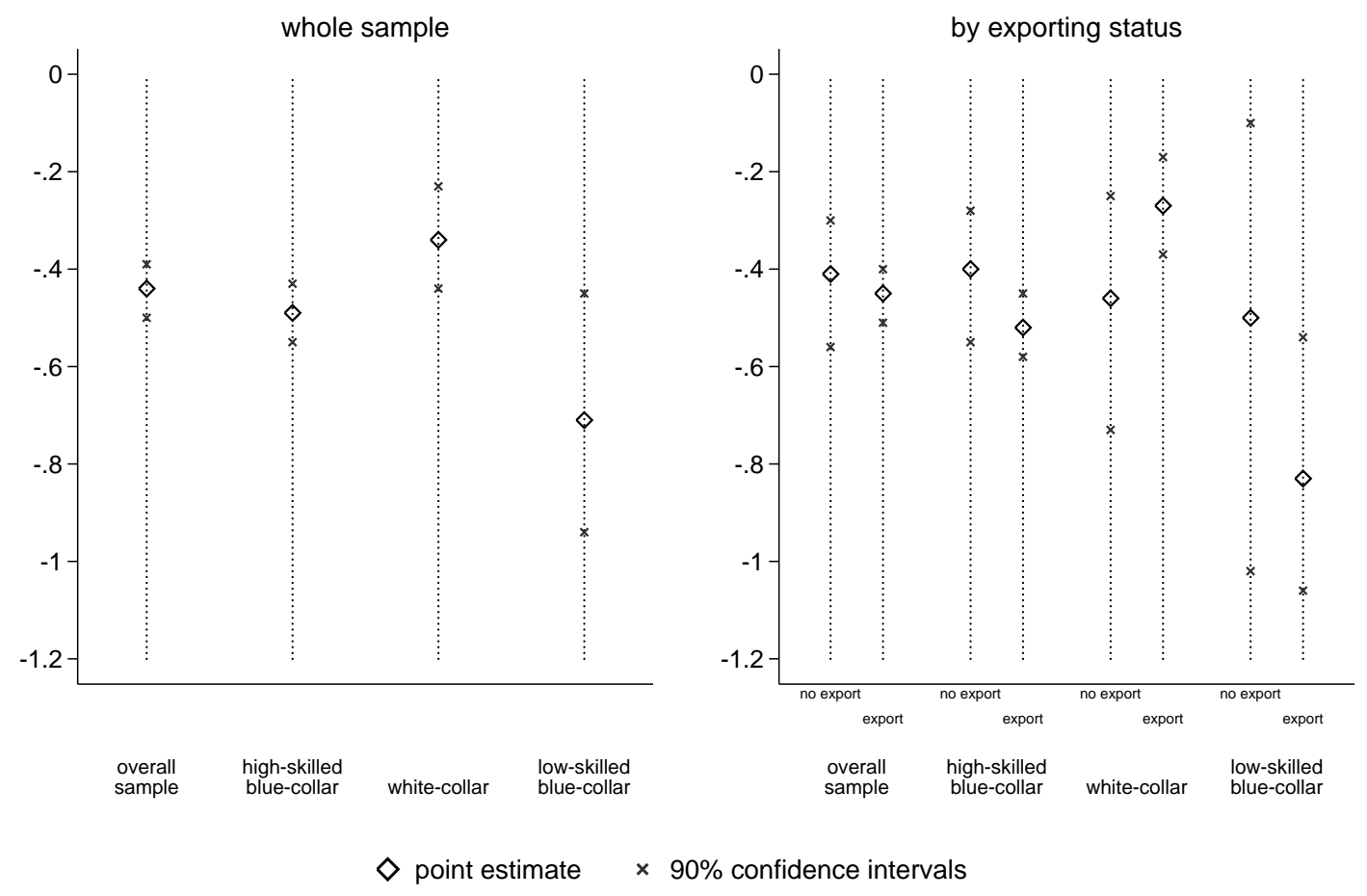

emerges when considering the demand elasticities for different skill groups: we do not find statistically different conditional own-wage labor demand elasticities between exporting and non-exporting establishments for any of the three skill groups. ${ }^{20}$ Interestingly, while conditional elasticities tend to be slightly higher for both types of blue-collar workers in exporting plants, the opposite seems to be true for whitecollar labor - at least when comparing point estimates. This could be cautiously interpreted in favor of Matsuyama (2007), whose model predicts that exporters have a relatively higher demand for skilled white-collar labor.

Price elasticity of product demand. In a final step, we use our estimates of both conditional and unconditional own-wage elasticities of labor demand to infer the price elasticity of product demand. Precisely, we follow Hijzen and Swaim (2010) in applying the 'fundamental law of factor demand' to derive price elasticities of product demand for exporting and non-exporting establishments. Notably, in our setting with three types of labor as the (only) production factors when estimating

${ }^{20}$ In line with Koebel et al. (2003), we report higher standard errors and confidence intervals for the estimated own-wage elasticities of those inputs with a low cost share. 
conditional labor demand, we account for the share of each skill group within each firm when deriving the price elasticity. The results are in line with the Hick-Marshall law of derived demand: we find that exporting establishments face more elastic product demand than non-exporting establishments (-0.67 vs. -0.28$){ }^{21}$ Table 5 summarizes the three key elasticities by establishment type.

Table 5: Overall mean elasticity estimates

\begin{tabular}{lccc}
\hline Establishment type & $\begin{array}{c}\text { Unconditional labor } \\
\text { demand elasticity }\end{array}$ & $\begin{array}{c}\text { Conditional labor } \\
\text { demand elasticity }\end{array}$ & $\begin{array}{c}\text { Price elasticity } \\
\text { of product demand }\end{array}$ \\
\hline Non-exporting establishments & -0.47 & -0.41 & -0.28 \\
Exporting establishments & -0.89 & -0.45 & -0.67 \\
Overall sample & -0.70 & -0.44 & -0.50 \\
Source: Own computations based on LIAB data.
\end{tabular}

\section{Conclusions}

In this paper, we show that globalization increases worker vulnerability by demonstrating that the exporting activity of firms increases own-wage elasticities of labor demand. Moreover, our empirical strategy allows us to identify the mechanism behind this relationship. In line with the Hicks-Marshall laws of derived demand, we show that higher price elasticities of product demand render own-wage elasticities of unconditional labor demand of exporting firms more elastic.

To account for observable and unobservable differences between exporting and non-exporting establishments, we control for issues of self-selection and endogeneity by providing fixed effects and instrumental variables estimates. Our results show that both exporting per se as well as the export share in total sales has a positive and significant effect on the own-wage elasticity of unconditional labor demand. In fact, we find that the own-wage elasticity for an average exporting establishment is around 10 to $15 \%$ higher than for a comparable non-exporting establishment. When explicitly accounting for differential demand for heterogeneous labor we further find exporting to render the demand for each type of labor more elastic.

\footnotetext{
${ }^{21}$ Note that our mean price elasticity of product demand of -0.50 is comparable to the estimate of -0.43 obtained by Hijzen and Swaim (2010).
} 
In order to identify whether higher unconditional own-wage elasticities for exporting establishments may be indeed explained by differences in price elasticities of product demand, we further derive own-wage elasticities conditional on output and thus abstract from any scale effect. Given that we find no significant differences in the overall conditional own-wage elasticities of labor demand for exporting and non-exporting establishments, we are able to infer that exporting establishments face more elastic product demand than non-exporting establishments and hence find evidence for the Hick-Marshall law of derived demand.

Our empirical findings might also suggest that wage premiums for workers employed in exporting firms may not be merely due to differences in productivity but may also serve as a compensation for higher job insecurity, given that these employees face higher employment volatility. Future research should explicitly analyze this link. In addition, a growing strand of literature questions the equivalence of skills and tasks implicitly given in standard production functions, arguing that the demand for tasks rather than for skills is affected by trade or technological developments (see, for example, Autor, 2013). Extending our analysis to firms' demand for tasks seems to be a particularly valuable, albeit difficult, step in future research. 


\section{References}

Alda, H., S. Bender, and H. Gartner (2005). The Linked Employer-Employee Dataset of the AB (LIAB). Journal of Applied Social Science Studies 125(2), $327-336$.

Autor, D. H. (2013). The 'Task Approach' to Labor Markets: An Overview. IZA Discussion Paper 7178.

Autor, D. H., D. Dorn, and G. Hanson (2013). The China Syndrome: Local Labor Market Effects of Import Competition in the United States. IZA Discussion Paper 7150. forthcomming in: American Economic Review.

Aw, B. Y., S. Chung, and M. J. Roberts (2000). Productivity and Turnover in the Export Market: Micro-level Evidence from the Republic of Korea and Taiwan (China). World Bank Economic Review 14(1), 65-90.

Bernard, A. B. and J. B. Jensen (1995). Exporters, Jobs, and Wages in U.S. manufacturing: 1976-87. In Brookings Papers on Economic Activity: Microeconomics, Volume 1995, pp. 67-112.

Bernard, A. B. and J. B. Jensen (1999). Exceptional exporter performance: cause, effect, or both? Journal of International Economics 47(1), 1-25.

Bernard, A. B., J. B. Jensen, S. J. Redding, and P. K. Schott (2007). Firms in International Trade. Journal of Economic Perspectives 21 (3), 105-130.

Berndt, E. R. (1991). The practice of econometrics: classic and contemporary. Reading, Mass.: Addison-Wesley.

Berndt, E. R. and D. O. Wood (1975). Technology, Prices, and the Derived Demand for Energy. The Review of Economics and Statistics, 57(3), 259-268.

Brambilla, I., D. Lederman, and G. Porto (2012). Exports, export destinations, and skills. American Economic Review 102(7), 3406-3438.

Buch, C. M. and A. Lipponer (2010). Volatile Multinationals? Evidence from the labor demand of German firms. Labour Economics 17(2), 345-353.

Bustos, P. (2011). Trade liberalization, exports, and technology upgrading: Evidence on the impact of mercosur on argentinian firms. Amercian Economic Review $101(1), 304-340$.

Clerides, S., S. Lach, and J. Tybout (1998). Is "Learning-by-Exporting" Important? Micro-Dynamic Evidence from Colombia, Mexico and Morocco. Quarterly Journal of Economics 454(3), 903-947.

De Loecker, J. (2007). Do exports generate higher productivity? Evidence from Slovenia. Journal of International Economics 73(1), 69-98.

Delgado, M. A., J. C. Farinas, and S. Ruanoc (2002). Firm productivity and export markets: a non-parametric approach. Journal of International Economics 57(2), $397-422$. 
Diewert, W. E. and T. J. Wales (1987). Flexible Functional Forms and Global Curvture Conditions. Econometrica 55(1), 43-68.

Fabbri, F., J. E. Haskel, and M. J. Slaughter (2003). Does Nationality Of Ownership Matter For Labor Demands? Journal of the European Economic Association 1(23), 698-707.

Fajnzylber, P. and A. Fernandez (2009). International economic activities and skilled labour demand: evidence from Brazil and China. Applied Economics 41 (5), 563577 .

Fajnzylber, P. and W. F. Maloney (2005). Labor demand and trade reform in Latin America. Journal of International Economics 66(2), 423-446.

Görg, H., M. Henry, E. Strobl, and F. Walsh (2009). Multinational companies, backward linkages, and labour demad elasticities. Canadian Journal of Economics 42(1), 332-348.

Hakkala, K. N., F. Heyman, and F. Sjöholm (2010). Multinationals, skills, and wage elasticities. Review of World Economics 146(2), 263-280.

Hamermesh, D. S. (1993). Labor Demand. Princeton: Princeton University Press.

Hasan, R., D. Mitra, and K. Ramaswamy (2007). Trade Reforms, Labor Regulations, And Labor Demand Elasticities: Empirical Evidence from India. The Review of Economics and Statistics 89(3), 466-481.

Helpman, E., O. Itskhoki, M.-A. Muendler, and S. Redding (2012). Trade and Inequality: From Theory to Estimation. CEP Discussion Paper Series 1138.

Hijzen, A., H. Görg, and R. C. Hine (2005). International Outsourcing And The Skill Structure Of Labor Demand In The United Kingdom. The Economic Journal 115(October), 860-878.

Hijzen, A. and P. Swaim (2010). Offshoring, labour market institutions and the elasticity of labour demand. European Economic Review 54(8), 1016-1034.

Koebel, B., M. Falk, and F. Lainsey (2003). Imposing and Tesing Curvature Conditions on a Box-Cox Cost Function. Journal of Business and Economic Statistics 21(2), 319-335.

Krishna, P., D. Mitra, and S. Chinoy (2001). Trade liberalization and labor demand elasticities: evidence from Turkey. Journal of International Economics 55(2), 391-409.

Matsuyama, K. (2007). Beyond icebergs: Towards a therory of biased globalization. The Review of Economic Studies 74(1), 237-253.

Mayer, T. and G. I. P. Ottaviano (2008). The Happy Few: The Internationalisation of Euroean Firms - New Facts based on Firm-level Evidence. Intereconomics 43(3), 135-148. 
Mitra, D. and J. Shin (2012). Import protection, exports and labor-demand elasticities: Evidence from Korea. International Review of Economics and Finance 23(C), 91-109.

Navaretti, G. B., D. Checci, and A. Turrini (2003). Adjusting Labor Demand: Multinational Versus National Firms: A Cross-European Analysis. Journal of the European Economic Association 1(2-3), 708-729.

Nguyen, D. X. and G. Schaur (2012). Import and export linkages transmit volatility across markets. Working Paper.

Peichl, A. and S. Siegloch (2012). Accounting for Labor Demand Effects in Structural Labor Supply Models. Labour Economics 19(1), 129-138.

Rodrik, D. (1997). Has Globalization Gone Too Far? Washington, D.C.: Institute For International Economics.

Schank, T., C. Schnabel, and J. Wagner (2007). Do exporters really pay higher wages? First evidence from German linked employer-employee data. Journal of International Economics 72(1), 52-74.

Senses, M. Z. (2010). The Effects of Offshoring on the Elasticitiy of Labor Demand. Journal of International Economics 81(1), 89-98.

Shephard, R. W. (1970). The Theory of Cost and Production. Princeton: Princeton University Press.

Slaughter, M. J. (2001). International trade and labor-demand elasticities. Journal of International Economics 54(1), 27-56.

Syverson, C. (2011). What Determines Productivity? Journal of Economic Literature $49(2), 326-365$.

Van Biesebroeck, J. (2005). Exporting Raises Productivity in Sub-Saharan African Manufacturing Plants. Journal of International Economics 67(2), 373-391.

Vannoorenberghe, G. (2012). Firm-level volatility and exports. Journal of International Economics 86(1), 57-67.

Wagner, J. (2007). Exports and Productivity in Germany. Applied Economics Quarterly 53(4), 353-373.

Wooldridge, J. M. (2010). Econometric analysis of cross section and panel data. The MIT Press.

World Trade Organization (Ed.) (2012). World trade developments.

Yalcin, E. and K. Zacher (2011). Zur Lage der deutschen Exporte. ifo Schnelldienst 64. Jahrgang (21), 17-25.

Zellner, A. (1962). An Efficient Method of Estimating Seemingly Unrelated Regressions and Tests of Aggregation Bias. Journal of the American Statistical Association 57(2), 348-368. 


\section{A Appendix: Descriptive Statistics}

Figure A.1: Export share on national GDP

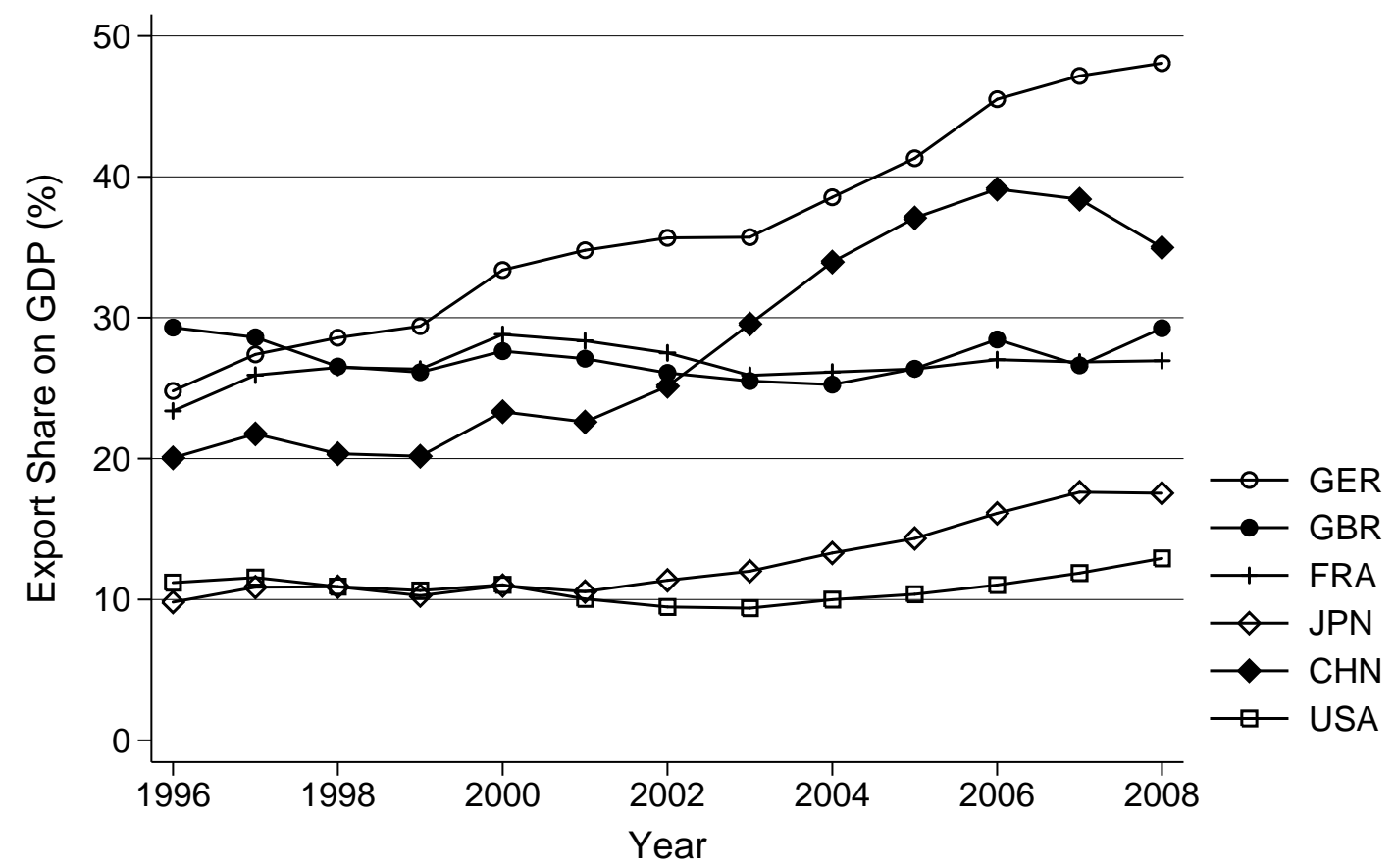

Source: http://data.worldbank.org/indicator/NE.EXP.GNFS.ZS

Table A.1: Bivariate OLS regressions

\begin{tabular}{lccc}
\hline & \multicolumn{3}{c}{ Export premium } \\
\cline { 2 - 4 } Establishment characteristics & $(1)$ & $(2)$ & $(3)$ \\
\hline Log no. of workers & 1.684 & - & - \\
Share of high-skilled blue-collar workers & -0.080 & -0.050 & -0.044 \\
Share of white-collar workers & 0.016 & 0.013 & 0.007 \\
Share of low-skilled blue-collar workers & 0.064 & 0.037 & 0.038 \\
Log wage & 0.271 & 0.096 & 0.074 \\
Log value-added per worker & 0.463 & 0.169 & - \\
Log output & 2.111 & 0.239 & - \\
Log investments per worker & 0.470 & 0.163 & 0.123 \\
Share of intermediate inputs & 0.034 & 0.041 & 0.069 \\
\hline Additional covariates: & no & number of workers & number of workers \& \\
& covariates & (in logs) & value-added (in logs)
\end{tabular}

Source: Own computations based on LIAB data. Note: Bivariate OLS estimation, regressing firm characteristics given in the left column on a dummy variable indicating firms' export behavior (no/yes). In column (2) we include the logarithmic number of workers and in column (3) the log value-added as additional controls. All estimates are significant at the one percent level. 


\section{B Appendix: IV Estimation - First-Stage Results}

Table B.2: Corresponding first-stage regression results for Table (3)

\begin{tabular}{lcc}
\hline (1) Export share & Whole sample & Exporting plants only \\
\hline Log wage & $-7.504^{* * *}$ & $-7.349^{* * *}$ \\
& $(1.749)$ & $(1.768)$ \\
Log investments & -0.120 & -.0578 \\
& $(0.109)$ & $(0.106)$ \\
Collective bargaining agreement & 0.139 & 0.169 \\
& $(0.407)$ & $(0.350)$ \\
Share of intermediate inputs & -1.072 & -2.324 \\
& $(0.786)$ & $(0.749)$ \\
Log exports to China & 0.783 & -0.687 \\
& $(0.828)$ & $(0.787)$ \\
Log exports to China*log wage & 0.141 & $0.269^{* * *}$ \\
& $(0.098)$ & $(0.091)$ \\
\hline No. of observations & 14,629 & 10,670 \\
No. groups & 3.613 & 2,717 \\
F-Test of excluded instruments & 39.41 & 39.15 \\
\hline
\end{tabular}

\begin{tabular}{lcc}
\hline (2) Interaction of wage and export share & Whole sample & Exporting plants only \\
\hline Log wage & $-59.275^{* * *}$ & $-58.185^{* * *}$ \\
& $(13.752)$ & $(14.022)$ \\
Log investments & -0.899 & -0.406 \\
& $(0.870)$ & $(0.847)$ \\
Collective bargaining agreement & 0.896 & 1.256 \\
& $(3.188)$ & $(2.754)$ \\
Share of intermediate inputs & -7.885 & $-18.206^{* * *}$ \\
& $(6.281)$ & $(5.993)$ \\
Log exports to China & -2.021 & $-13.487^{* *}$ \\
& $(6.541)$ & $(6.257)$ \\
Log exports to China*log wage & $2.13^{* * *}$ & $3.135^{* * *}$ \\
& $(0.770)$ & $(0.723)$ \\
\hline No. of observations & 14,629 & 10,670 \\
No. of groups & 3.613 & 2717 \\
F-Test of excluded instruments & 42.55 & 45.37 \\
\hline
\end{tabular}

Source: Own computations based on LIAB data. Note: All specifications include establishment and industry-year fixed effects. Standard errors (in parentheses) in column (1) are clustered at the establishment level. Significance levels are $0.1\left(^{*}\right), 0.05(* *)$, and $0.01(* *)$. 


\section{Appendix: Heterogeneous Labor Demand}

Table C.3: Heterogeneous labor demand and exporting: fixed effects estimates

\begin{tabular}{|c|c|c|c|c|c|c|}
\hline \multirow[b]{2}{*}{ Dep. var.: log number of skilled workers } & \multicolumn{3}{|c|}{ Extensive margin } & \multicolumn{3}{|c|}{ Intensive margin } \\
\hline & high/blue & white & low/blue & high/blue & white & low/blue \\
\hline Log high-skilled blue-collar wage & $\begin{array}{c}-1.022^{* * *} \\
(0.126)\end{array}$ & $\begin{array}{l}-0.074 \\
(0.091)\end{array}$ & $\begin{array}{l}-0.231 \\
(0.151)\end{array}$ & $\begin{array}{c}-1.013^{* * *} \\
(0.125)\end{array}$ & $\begin{array}{l}-0.063 \\
(0.091)\end{array}$ & $\begin{array}{l}-0.194 \\
(0.145)\end{array}$ \\
\hline Log white-collar wage & $\begin{array}{c}0.075 \\
(0.059)\end{array}$ & $\begin{array}{c}-0.268^{* * *} \\
(0.076)\end{array}$ & $\begin{array}{l}-0.056 \\
(0.072)\end{array}$ & $\begin{array}{c}0.077 \\
(0.059)\end{array}$ & $\begin{array}{c}-0.248^{* * *} \\
(0.074)\end{array}$ & $\begin{array}{l}-0.056 \\
(0.069)\end{array}$ \\
\hline Log low-skilled blue-collar wage & $\begin{array}{c}0.190^{* * *} \\
(0.043)\end{array}$ & $\begin{array}{c}0.058 \\
(0.039)\end{array}$ & $\begin{array}{c}-0.617^{* * *} \\
(0.072)\end{array}$ & $\begin{array}{c}0.190^{* * *} \\
(0.043)\end{array}$ & $\begin{array}{c}0.056 \\
(0.039)\end{array}$ & $\begin{array}{c}-0.633^{* * *} \\
(0.070)\end{array}$ \\
\hline Log high-skilled blue-collar wage*export & $\begin{array}{c}-0.095^{*} \\
(0.052)\end{array}$ & & & & & \\
\hline Log white-collar wage*export & & $\begin{array}{c}-0.071^{*} \\
(0.041)\end{array}$ & & & & \\
\hline Log low-skilled blue-collar wage*export & & & $\begin{array}{l}-0.044 \\
(0.052)\end{array}$ & & & \\
\hline Log high-skilled blue-collar wage*export share & & & & $\begin{array}{c}-0.003^{* *} \\
(0.001)\end{array}$ & & \\
\hline Log white-collar wage*export share & & & & & $\begin{array}{c}-0.004^{* * *} \\
(0.001)\end{array}$ & \\
\hline Log low-skilled blue-collar wage*export share & & & & & & $\begin{array}{l}-0.002 \\
(0.001)\end{array}$ \\
\hline Export dummy & $\begin{array}{l}0.777^{*} \\
(0.410)\end{array}$ & $\begin{array}{l}0.608^{*} \\
(0.330)\end{array}$ & $\begin{array}{c}0.373 \\
(0.404)\end{array}$ & & & \\
\hline Export share & & & & $\begin{array}{c}0.026^{* *} \\
(0.010)\end{array}$ & $\begin{array}{c}0.033^{* * *} \\
(0.011)\end{array}$ & $\begin{array}{c}0.014 \\
(0.010)\end{array}$ \\
\hline Collective bargaining agreement & $\begin{array}{c}0.005 \\
(0.016)\end{array}$ & $\begin{array}{c}-0.024^{*} \\
(0.014)\end{array}$ & $\begin{array}{l}-0.016 \\
(0.023)\end{array}$ & $\begin{array}{c}0.005 \\
(0.016)\end{array}$ & $\begin{array}{c}-0.023^{*} \\
(0.014)\end{array}$ & $\begin{array}{l}-0.014 \\
(0.023)\end{array}$ \\
\hline Log investments & $\begin{array}{c}0.028^{* * *} \\
(0.003)\end{array}$ & $\begin{array}{c}0.023^{* * *} \\
(0.003)\end{array}$ & $\begin{array}{c}0.033^{* * *} \\
(0.004)\end{array}$ & $\begin{array}{c}0.028^{* * *} \\
(0.003)\end{array}$ & $\begin{array}{c}0.022^{* * *} \\
(0.003)\end{array}$ & $\begin{array}{c}0.030^{* * *} \\
(0.004)\end{array}$ \\
\hline (Share of intermediate inputs/100) & $\begin{array}{l}-0.018 \\
(0.012)\end{array}$ & $\begin{array}{c}-0.036^{* * *} \\
(0.014)\end{array}$ & $\begin{array}{l}-0.006 \\
(0.018)\end{array}$ & $\begin{array}{l}-0.018 \\
(0.013)\end{array}$ & $\begin{array}{c}-0.035^{* *} \\
(0.013)\end{array}$ & $\begin{array}{l}-0.002 \\
(0.018)\end{array}$ \\
\hline No. of observations & 16,270 & 16,270 & 16,270 & 16,270 & 16,270 & 16,270 \\
\hline No. of groups & 4,100 & 4,100 & 4,100 & 4,100 & 4,100 & 4,100 \\
\hline Overall R-Squared & 0.023 & 0.031 & 0.086 & 0.021 & 0.033 & 0.039 \\
\hline
\end{tabular}

Source: Own computations based on LIAB data. Note: All specifications include year and year*branch fixed effects. The constant is omitted for the ease of presentation. Standard errors (in parentheses) are clustered at the establishment level. Significance levels are $0.1\left(^{*}\right), 0.05(* *)$, and $0.01(* * *)$. Note than "high blue", "white" and "low blue" denote the log number of high-skilled blue-collar, white-collar and low-skilled blue-collar workers, respectively. 


\section{Appendix: Conditional Labor Demand}

As given by Diewert and Wales (1987), we define costs $\mathrm{C}$ according to:

$$
\begin{aligned}
\ln C\left(w_{i}, Y\right)= & \alpha_{0}+\sum_{i=1}^{n} \alpha_{i} \ln w_{i}+0.5 \sum_{i=1}^{n} \sum_{j=1}^{n} \alpha_{i j} \ln w_{i} \ln w_{j}+\beta_{Y} \ln Y \\
& +\sum_{i=1}^{n} \beta_{i Y} \ln w_{i} \ln Y+0.5 \beta_{Y Y}(\ln Y)^{2}+\eta_{t} t
\end{aligned}
$$

In order to ensure linear homogeneity in factor prices as well as to allow for nonconstant returns to scale, several restrictions on the parameters are imposed:

$$
\alpha_{i j}=\alpha_{j i} \quad \sum_{i=1}^{n} \alpha_{i}=1 \quad \sum_{i=1}^{n} \alpha_{i j}=0 \quad \sum_{i=1}^{n} \beta_{i Y}=0 .
$$

Applying Shephard's lemma (Shephard, 1970) and exploiting the fact that the cost function is logarithmized, the cost shares may be denoted as:

$$
S_{i}=\frac{w_{i} X_{i}}{C}=\frac{\partial \ln C\left(w_{i}, Y\right)}{\partial \ln w_{i}}=\alpha_{i}+\sum_{j=1}^{n} \alpha_{i j} \ln w_{j}+\beta_{i Y} \ln y+\eta_{t} t+\varepsilon_{i t} \quad \forall i .
$$

We estimate the cost function jointly with N-1 share equations by SUR, accounting for establishment fixed effects by demeaning the data.

Table D.4: Conditional labor demand elasticities and corresponding standard errors

\begin{tabular}{cccc}
\hline Own-Wage Elasticity & $\begin{array}{c}\text { Non-exporting } \\
\text { plants only }\end{array}$ & $\begin{array}{c}\text { Exporting } \\
\text { plants only }\end{array}$ & $\begin{array}{c}\text { Whole } \\
\text { sample }\end{array}$ \\
\hline High-skilled blue-collar & -0.40 & -0.52 & -0.49 \\
White-collar & $(0.08)$ & $(0.04)$ & $(0.04)$ \\
Low-skilled blue-collar & -0.46 & -0.27 & -0.34 \\
& $(0.15)$ & $(0.09)$ & $(0.06)$ \\
Overall & -0.50 & -0.83 & -0.71 \\
& $(0.32)$ & $(0.16)$ & $(0.29)$ \\
& -0.41 & -0.45 & -0.44 \\
& $(0.06)$ & $(0.03)$ & $(0.03)$ \\
\hline
\end{tabular}

Source: Own computations based on LIAB data. Note: Mean own-wage elasticities of heterogeneous labor demand. Standard errors (in parentheses) obtained from bootstrapping using 400 replications. 
Table D.5: Conditional labor demand estimates for non-exporting establishments

\section{Theoretical Fit:}

Share of predicted cost shares $<0: 0$

Share of strict quasi-concave cost functions: $90.11 \%$

Share of violated adding-up conditions: 0

\begin{tabular}{|c|c|c|c|}
\hline Dependent Variable: & Cost share $\left(\ln l^{w}\right)$ & Cost share $\left(\ln l^{l b}\right)$ & Cost function (C) \\
\hline $\operatorname{Ln}\left(w^{w}\right) / \operatorname{Ln}\left(w^{h b}\right)$ & $\begin{array}{l}0.050^{* * *} \\
(0.010)\end{array}$ & $\begin{array}{l}-0.025^{* * *} \\
(0.007)\end{array}$ & \\
\hline $\operatorname{Ln}\left(w^{l b}\right) / \operatorname{Ln}\left(w^{h b}\right)$ & $\begin{array}{l}-0.025^{* * *} \\
(0.007)\end{array}$ & $\begin{array}{l}0.024^{* *} \\
(0.009)\end{array}$ & \\
\hline Ln(value-added) & $\begin{array}{l}0.001 \\
(0.001)\end{array}$ & $\begin{array}{l}0.002^{*} \\
(0.001)\end{array}$ & $\begin{array}{l}-0.057 \\
(0.049)\end{array}$ \\
\hline $\operatorname{Ln}\left(w^{h b}\right)$ & & & $\begin{array}{l}1.000^{* * *} \\
(0.001)\end{array}$ \\
\hline $\operatorname{Ln}\left(w^{w}\right)$ & & & $\begin{array}{l}-0.000 \\
(0.001)\end{array}$ \\
\hline $\operatorname{Ln}\left(w^{l b}\right)$ & & & $\begin{array}{l}-0.000 \\
(0.001)\end{array}$ \\
\hline $\operatorname{Ln}\left(w^{w}\right)^{*} \ln \left(w^{l b}\right)$ & & & $\begin{array}{l}-0.025^{* * *} \\
(0.007)\end{array}$ \\
\hline $\operatorname{Ln}\left(w^{w}\right)^{*} \ln \left(w^{h b}\right)$ & & & $\begin{array}{l}-0.026^{* * *} \\
(0.010)\end{array}$ \\
\hline $\operatorname{Ln}\left(w^{l b}\right)^{*} \ln \left(w^{h b}\right)$ & & & $\begin{array}{l}0.001 \\
(0.010)\end{array}$ \\
\hline $\operatorname{Ln}\left(w^{h b}\right)^{*} \ln ($ value-added $)$ & & & $\begin{array}{l}-0.003^{* *} \\
(0.001)\end{array}$ \\
\hline $\operatorname{Ln}\left(w^{w}\right)^{*} \ln ($ value-added $)$ & & & $\begin{array}{l}0.001^{* * *} \\
(0.001)\end{array}$ \\
\hline $\operatorname{Ln}\left(w^{l b}\right)^{*} \ln ($ value-added $)$ & & & $\begin{array}{l}0.002^{*} \\
(0.001)\end{array}$ \\
\hline $\operatorname{Ln}\left(w^{h b}\right)^{2}$ & & & $\begin{array}{l}0.025^{*} \\
(0.014)\end{array}$ \\
\hline $\operatorname{Ln}\left(w^{w}\right)^{2}$ & & & $\begin{array}{l}0.050^{* * *} \\
(0.010)\end{array}$ \\
\hline $\operatorname{Ln}\left(w^{l b}\right)^{2}$ & & & $\begin{array}{l}0.024^{* *} \\
(0.010)\end{array}$ \\
\hline $\operatorname{Ln}(\text { value-added })^{2}$ & & & $\begin{array}{c}0.008^{* *} \\
(0.003)\end{array}$ \\
\hline Number of observations & 2,914 & 2,914 & 2,914 \\
\hline Parameters & 15 & 15 & 21 \\
\hline
\end{tabular}

Source: Own computations based on LIAB data. Note: All equations include year-fixed effects and a constant term. Standard errors (in parentheses). Significance levels are $0.1\left(^{*}\right), 0.05\left(^{* *}\right)$, and $0.01(* * *)$. 
Table D.6: Conditional labor demand estimates for exporting establishments

\section{Theoretical Fit:}

Share of predicted cost shares $<0: 0.001$

Share of strict quasi-concave cost functions: $87.43 \%$

Share of violated adding-up conditions: 0

\begin{tabular}{|c|c|c|c|}
\hline Dependent Variable: & Cost share $\left(\ln l^{w}\right)$ & Cost share $\left(\ln l^{l b}\right)$ & Cost function $(\mathrm{C})$ \\
\hline $\operatorname{Ln}\left(w^{w}\right) / \operatorname{Ln}\left(w^{h b}\right)$ & $\begin{array}{l}0.093^{* * *} \\
(0.006)\end{array}$ & $\begin{array}{l}-0.052^{* * *} \\
(0.004)\end{array}$ & \\
\hline $\operatorname{Ln}\left(w^{l b}\right) / \operatorname{Ln}\left(w^{h b}\right)$ & $\begin{array}{l}-0.052^{* * *} \\
(0.004)\end{array}$ & $\begin{array}{l}-0.001 \\
(0.005)\end{array}$ & \\
\hline Ln(value-added) & $\begin{array}{l}0.001^{*} \\
(0.000)\end{array}$ & $\begin{array}{l}0.003^{* * *} \\
(0.000)\end{array}$ & $\begin{array}{l}-0.020 \\
(0.029)\end{array}$ \\
\hline $\operatorname{Ln}\left(w^{h b}\right)$ & & & $\begin{array}{l}1.000^{* * *} \\
(0.000)\end{array}$ \\
\hline $\operatorname{Ln}\left(w^{w}\right)$ & & & $\begin{array}{l}0.000 \\
(0.000)\end{array}$ \\
\hline $\operatorname{Ln}\left(w^{l b}\right)$ & & & $\begin{array}{l}-0.000 \\
(0.000)\end{array}$ \\
\hline $\operatorname{Ln}\left(w^{w}\right)^{*} \ln \left(w^{l b}\right)$ & & & $\begin{array}{l}-0.052^{* * *} \\
(0.004)\end{array}$ \\
\hline $\operatorname{Ln}\left(w^{w}\right)^{*} \ln \left(w^{h b}\right)$ & & & $\begin{array}{l}-0.041^{* * *} \\
(0.005)\end{array}$ \\
\hline $\operatorname{Ln}\left(w^{l b}\right)^{*} \ln \left(w^{h b}\right)$ & & & $\begin{array}{l}0.053^{* * *} \\
(0.005)\end{array}$ \\
\hline $\operatorname{Ln}\left(w^{h b}\right) * \ln ($ value-added $)$ & & & $\begin{array}{l}-0.004^{* * *} \\
(0.001)\end{array}$ \\
\hline $\operatorname{Ln}\left(w^{w}\right)^{*} \ln ($ value-added $)$ & & & $\begin{array}{l}0.001^{*} \\
(0.000)\end{array}$ \\
\hline $\operatorname{Ln}\left(w^{l b}\right)^{*} \ln ($ value-added $)$ & & & $\begin{array}{l}0.003^{* * *} \\
(0.000)\end{array}$ \\
\hline $\operatorname{Ln}\left(w^{h b}\right)^{2}$ & & & $\begin{array}{l}-0.013^{*} \\
(0.007)\end{array}$ \\
\hline $\operatorname{Ln}\left(w^{w}\right)^{2}$ & & & $\begin{array}{l}0.093^{* * *} \\
(0.006)\end{array}$ \\
\hline $\operatorname{Ln}\left(w^{l b}\right)^{2}$ & & & $\begin{array}{l}-0.001 \\
(0.005)\end{array}$ \\
\hline $\operatorname{Ln}(\text { value-added })^{2}$ & & & $\begin{array}{l}0.005^{* * *} \\
(0.002)\end{array}$ \\
\hline Number of observations & 10,967 & 10,967 & 10,967 \\
\hline Parameters & 15 & 15 & 21 \\
\hline
\end{tabular}

Source: Own computations based on LIAB data. Note: All equations include year-fixed effects and a constant term. Standard errors (in parentheses). Significance levels are $0.1\left(^{*}\right), 0.05\left(^{* *}\right)$, and $0.01(* * *)$. 
Table D.7: Conditional labor demand estimates for the whole sample

\section{Theoretical Fit:}

Share of predicted cost shares $<0: 0.001$

Share of strict quasi-concave cost functions: $88.55 \%$

Share of violated adding-up conditions: 0

\begin{tabular}{|c|c|c|c|}
\hline Dependent Variable: & Cost share $\left(\ln l^{w}\right)$ & Cost share $\left(\ln l^{l b}\right)$ & Cost function $(\mathrm{C})$ \\
\hline $\operatorname{Ln}\left(w^{w}\right) / \operatorname{Ln}\left(w^{h b}\right)$ & $\begin{array}{l}0.080^{* * *} \\
(0.005)\end{array}$ & $\begin{array}{l}-0.045^{* * *} \\
(0.003)\end{array}$ & \\
\hline $\operatorname{Ln}\left(w^{l b}\right) / \operatorname{Ln}\left(w^{h b}\right)$ & $\begin{array}{l}-0.045^{* * *} \\
(0.003)\end{array}$ & $\begin{array}{l}0.007^{*} \\
(0.004)\end{array}$ & \\
\hline Ln(value-added) & $\begin{array}{l}0.001^{* *} \\
(0.000)\end{array}$ & $\begin{array}{l}0.003^{* * *} \\
(0.000)\end{array}$ & $\begin{array}{l}-0.034 \\
(0.024)\end{array}$ \\
\hline $\operatorname{Ln}\left(w^{h b}\right)$ & & & $\begin{array}{l}1.000^{* * *} \\
(0.000)\end{array}$ \\
\hline $\operatorname{Ln}\left(w^{w}\right)$ & & & $\begin{array}{l}0.000 \\
(0.000)\end{array}$ \\
\hline $\operatorname{Ln}\left(w^{l b}\right)$ & & & $\begin{array}{l}0.000 \\
(0.000)\end{array}$ \\
\hline $\operatorname{Ln}\left(w^{w}\right)^{*} \ln \left(w^{l b}\right)$ & & & $\begin{array}{l}-0.045^{* * *} \\
(0.003)\end{array}$ \\
\hline $\operatorname{Ln}\left(w^{w}\right)^{*} \ln \left(w^{h b}\right)$ & & & $\begin{array}{l}-0.035^{* * *} \\
(0.004)\end{array}$ \\
\hline $\operatorname{Ln}\left(w^{l b}\right) * \ln \left(w^{h b}\right)$ & & & $\begin{array}{l}0.037^{* * *} \\
(0.004)\end{array}$ \\
\hline $\operatorname{Ln}\left(w^{h b}\right) * \ln ($ value-added $)$ & & & $\begin{array}{l}-0.004^{* * *} \\
(0.000)\end{array}$ \\
\hline $\operatorname{Ln}\left(w^{w}\right)^{*} \ln ($ value-added $)$ & & & $\begin{array}{l}0.001^{* *} \\
(0.001)\end{array}$ \\
\hline $\operatorname{Ln}\left(w^{l b}\right)^{*} \ln ($ value-added $)$ & & & $\begin{array}{l}0.003^{* * *} \\
(0.001)\end{array}$ \\
\hline $\operatorname{Ln}\left(w^{h b}\right)^{2}$ & & & $\begin{array}{l}-0.002 \\
(0.006)\end{array}$ \\
\hline $\operatorname{Ln}\left(w^{w}\right)^{2}$ & & & $\begin{array}{l}0.080^{* * *} \\
(0.005)\end{array}$ \\
\hline $\operatorname{Ln}\left(w^{l b}\right)^{2}$ & & & $\begin{array}{l}0.007^{*} \\
(0.004)\end{array}$ \\
\hline $\operatorname{Ln}(\text { value-added })^{2}$ & & & $\begin{array}{l}0.006^{* * *} \\
(0.001)\end{array}$ \\
\hline Number of observations & 13,881 & 13,881 & 13,881 \\
\hline Parameters & 15 & 15 & 21 \\
\hline
\end{tabular}

Source: Own computations based on LIAB data. Note: All equations include year-fixed effects and a constant term. Standard errors (in parentheses). Significance levels are $0.1\left(^{*}\right), 0.05\left(^{* *}\right)$, and $0.01(* * *)$. 